\title{
The Chemical Constituents of Ellipeia cuneifolia and Their Antibacterial Activity
}

(Komposisi Kimia Ellipeia cuneifolia dan Aktiviti Antibakterianya)

\author{
HaSliZa Yusof, Laily B. Din, WAN A. YAACOB*, NAZLINA IBRAHIM, \\ BOHARI M. YAMIN \& A. LATIFF
}

\begin{abstract}
Chromatographic purification of chloroform extract of the twigs of Ellipeia cuneifolia has led to the discovery of three compounds comprising of 2',4'-dihydroxy-4,6'-dimethoxychalcone; tepanone; and O-methylmoschatoline. Structures of the compounds were established by interpreting their spectral data and by comparing them with those of the literature. Two of them showed antibacterial activities.
\end{abstract}

Keywords: Annonaceae; antibacterial activity; chalcone; Ellipeia cuneifolia; oxoaporphine; retrochalcone; twig

ABSTRAK

Penulenan kromatografi terhadap ekstrak kloroform ranting Ellipeia cuneifolia membawa kepada penemuan 3 sebatian iaitu 2',4'-dihidroksi-4,6'-dimetoksikalkon; tepanon; dan O-metilmoskatolina. Struktur sebatian ini telah ditentukan dengan mentafsirkan data spektrum dan membandingkannya dengan data spektrum daripada penerbitan. Dua daripadanya menunjukkan aktiviti antibakteria.

Kata kunci: Aktiviti antibakteria; Annonaceae; Ellipeia cuneifolia; kalkon; oksoaporfina; ranting; retrokalkon

\section{INTRODUCTION}

Ellipeia Hook \& Thom. of the family Annonaceae is a very small genus of climbers with about merely five species and known to be distributed in Peninsular Malaysia, Borneo and Sumatra (Kessler 1993). In Peninsular Malaysia only one species of $E$. cuneifolia occurs, mostly in the northeastern coast of peninsula (Ridley 1922; Sinclair 1955). Locally the plant is known as tepan and according to local herbalists, a decoction of the roots has been used for post-parturition. Previously, Colegate et al. (1992) reported the isolation of a new retrochalcone, tepanone. A reinvestigation of the plant collected from the same locality showed two chalcones and one alkaloid, besides tepanone ((2E)-1-phenyl-3-(2'-hydroxy-3',4',6'-trimethoxyphenyl) prop-2-enone). In this study, we report the results of a phytochemical investigation of the twigs. Compounds 1 showed inhibitory against Bacillus subtilis, Enterobacter aerogenes and Escherichia coli, whereas compound 3 exhibited very strong activities against $B$. subtilis and Staphylococcus aureus.

\section{MATERIALS AND METHODS}

\section{GENERAL}

The ${ }^{1} \mathrm{H}$ and ${ }^{13} \mathrm{C}$ NMR spectra were recorded with Avance III $600 \mathrm{MHz}$ Bruker in $\mathrm{CDCl}_{3}$ and acetone- $d_{6}$ with the chemical shifts, $\delta$, in ppm and the values of coupling constants, $J$ in Hz. LC-MSToF spectra were taken on the Dionex/Bruker Micro ToFQ, FTIR spectra were recorded on the Perkin Elmer Spectrum 400 FT-IR/FT-NIR and UV spectrophotometer Shimadzu UV-160 (200-400 nm).

\section{PLANT MATERIAL}

Twigs of Ellipeia cuneifolia were collected in October 2011 from the coastal area of Kota Bharu, Kelantan. A voucher specimen (ALM 3142) was deposited at the herbarium of Universiti Kebangsaan Malaysia, Bangi.

\section{EXTRACTION AND ISOLATION}

Dried ground twigs of Ellipeia cuneifolia $(0.95 \mathrm{~kg})$ were steeped three times in chloroform at room temperature over three days each to give $7.86 \mathrm{~g}(0.83 \%)$ of a darkgreen extract after solvent removal by a rotary evaporator. The $\mathrm{CHCl}_{3}$ extract was subjected to vacuum liquid chromatography (VLC) by using silica 7747 (Merck) eluted with increasing polarity of $n$-hexane and ethyl acetate. The eluates were combined based on their silica gel thin layer chromatography (TLC) (Merck 5554) profile to yield seven fractions (A-G). Fraction D (0.48 g) was purified by column chromatography (CC), preparative TLC and Sephadex LH-20 to give compounds 1 (3.4 mg). Fractions $\mathrm{E}(0.85 \mathrm{~g})$ and $\mathrm{G}(0.56 \mathrm{~g})$ were separately purified by $\mathrm{CC}$ to give compounds $2(3.2 \mathrm{mg})$ and $3(5.8 \mathrm{mg})$, respectively.

$2^{\prime}, 4^{\prime}$-Dihydroxy-4,6' -dimethoxychalcone 1 (3.4 mg): white needles; $\mathrm{R}_{\mathrm{f}}=0.78$ (4:6, $n$-hexane-ethyl acetate); ESIMS (m/z): $323.0891[\mathrm{M}+\mathrm{Na}]^{+}, \mathrm{C}_{17} \mathrm{H}_{16} \mathrm{O}_{5}$; UV (MeOH) $\lambda_{\text {max }}$ : 226, 292, $357 \mathrm{~nm}$; FTIR (ATR) $\mathrm{cm}^{-1}: 3241,2940,1623,1609$, $1511,1196,1109,789 ;{ }^{1} \mathrm{H}$ NMR (acetone- $\left.d_{6}, 600 \mathrm{MHz}\right) \delta_{\mathrm{H}}$ : 
$7.90(1 \mathrm{H}, d, J=15.3 \mathrm{~Hz}, \mathrm{H}-\alpha), 7.74(1 \mathrm{H}, d, J=15.3 \mathrm{~Hz}$, $\mathrm{H}-\beta), 7.68(2 \mathrm{H}, d, J=8.7 \mathrm{~Hz}, \mathrm{H}-2,6), 7.00(2 \mathrm{H}, d, J=$ $8.7 \mathrm{~Hz}, \mathrm{H}-3,5), 6.06\left(1 \mathrm{H}, d, J=2.1 \mathrm{~Hz}, \mathrm{H}-5^{\prime}\right), 5.98(1 \mathrm{H}$, $\left.d, J=2.1 \mathrm{~Hz}, \mathrm{H}-3^{\prime}\right), 3.96\left(3 \mathrm{H}, s, 6^{\prime}-\mathrm{OCH}_{3}\right), 3.86(3 \mathrm{H}, s$, $\left.4-\mathrm{OCH}_{3}\right) ;{ }^{13} \mathrm{C}$-APT NMR (acetone- $\left.d_{6}, 150 \mathrm{MHz}\right) \delta_{\mathrm{C}}: 192.2$ (C-9), 168.1 (C-2'), 165.1 (C-4'), 163.4 (C-6'), 161.7 (C4), 142.1 (C- $\beta), 130.2$ (C-2, 6), 128.1 (C-1), 125.0 (C- $\alpha)$, $114.4(\mathrm{C}-3,5), 105.4\left(\mathrm{C}-1^{\prime}\right), 96.1\left(\mathrm{C}-3^{\prime}\right), 91.3\left(\mathrm{C}-5^{\prime}\right), 55.5$ $\left(6^{\prime}-\mathrm{OCH}_{3}\right), 54.9\left(4-\mathrm{OCH}_{3}\right)$.

Tepanone 2 (3.2 mg): yellow needles; $\mathrm{R}_{\mathrm{f}}=0.69$ (4:6, $n$-hexane-ethyl acetate); ESI-MS (m/z): $337.1005, \mathrm{C}_{18} \mathrm{H}_{18} \mathrm{O}_{5}$; $\mathrm{UV}(\mathrm{MeOH}) \lambda_{\text {max }}: 224,257,364 \mathrm{~nm}$; FTIR (ATR) $\mathrm{cm}^{-1}: 3306$, 2847-2998, 1639, 1551, 1466, 1337, 1110, 1203,847, 793; ${ }^{1} \mathrm{H}$ NMR $\left(\mathrm{CDCl}_{3}, 600 \mathrm{MHz}\right) \delta_{\mathrm{H}}: 8.23(1 \mathrm{H}, d, J=16.2 \mathrm{~Hz}$, $\mathrm{H}-\beta), 8.04\left(2 \mathrm{H}, d, J=7.2 \mathrm{~Hz}, \mathrm{H}-2^{\prime}, 6^{\prime}\right), 8.00(1 \mathrm{H}, d, J=$ $16.2 \mathrm{~Hz}, \mathrm{H}-\alpha), 7.55\left(1 \mathrm{H}, t, J=7.2 \mathrm{~Hz}, \mathrm{H}-4^{\prime}\right), 7.48(2 \mathrm{H}, t$, $\left.J=7.5 \mathrm{~Hz}, \mathrm{H}-3^{\prime}, 5^{\prime}\right), 6.09$ (1H, $\left.s, \mathrm{H}-5\right), 6.61(1 \mathrm{H}, s, 2-\mathrm{OH})$, $3.94\left(3 \mathrm{H}, s, 4 / 6-\mathrm{OCH}_{3}\right), 3.90\left(3 \mathrm{H}, s, 4 / 6-\mathrm{OCH}_{3}\right), 3.88(3 \mathrm{H}$, $\left.s, 3-\mathrm{OCH}_{3}\right) ;{ }^{13} \mathrm{C} \mathrm{NMR}\left(\mathrm{CDCl}_{3}, 150 \mathrm{MHz}\right) \delta_{\mathrm{C}}: 191.9(\mathrm{C}-9)$, 156.9 (C-6), 154.0 (C-4), 150.6 (C-2), 139.1 (C-1'), 135.8 $(\mathrm{C}-\beta), 132.2\left(\mathrm{C}-4^{\prime}\right), 129.7$ (C-3), $128.5\left(\mathrm{C}-2^{\prime}, 6^{\prime}\right), 128.4$ (C-3', 5'), $122.5(\mathrm{C}-\alpha), 105.2(\mathrm{C}-1), 88.2$ (C-5), 61.3 (3$\left.\mathrm{OCH}_{3}\right), 56.0\left(4 / 6-\mathrm{OCH}_{3}\right), 55.9\left(4 / 6-\mathrm{OCH}_{3}\right)$.

$o$-Methylmoschatoline $3(5.8 \mathrm{mg})$ : orange needles. $\mathrm{R}_{\mathrm{f}}=$ 0.39 (4:6, $n$-hexane-ethyl acetate). ESI-MS (m/z): 322.1098 $[\mathrm{M}+\mathrm{H}]^{+}, \mathrm{C}_{19} \mathrm{H}_{15} \mathrm{O}_{4} \mathrm{~N}$. FTIR (ATR) $\mathrm{cm}^{-1}: 3127,3069,2948$, 2858, 1657, 1578, 1465, 1384, 1202, 1089, 935, 755. ${ }^{1} \mathrm{H}$ NMR $\left(\mathrm{CDCl}_{3}, 600 \mathrm{MHz}\right) \delta_{\mathrm{H}}: 9.11(1 \mathrm{H}, d, J=8.4 \mathrm{~Hz}$, $\mathrm{H}-11), 8.97(1 \mathrm{H}, d, J=5.4 \mathrm{~Hz}, \mathrm{H}-5), 8.58(1 \mathrm{H}, d d, J=$ $1.2,7.8 \mathrm{~Hz}, \mathrm{H}-8), 8.22(1 \mathrm{H}, d, J=5.4 \mathrm{~Hz}, \mathrm{H}-4), 7.75(1 \mathrm{H}$, $d t, J=1.2,8.4 \mathrm{~Hz}, \mathrm{H}-10), 7.54(1 \mathrm{H}, t, J=7.8 \mathrm{~Hz}, \mathrm{H}-9)$, $4.20\left(3 \mathrm{H}, s, 3-\mathrm{OCH}_{3}\right), 4.11\left(3 \mathrm{H}, s, 2-\mathrm{OCH}_{3}\right), 4.09(3 \mathrm{H}, s$, $\left.1-\mathrm{OCH}_{3}\right) .{ }^{13} \mathrm{C} \mathrm{NMR}\left(\mathrm{CDCl}_{3}, 150 \mathrm{MHz}\right) \delta_{\mathrm{C}}: 182.7(\mathrm{C}-7)$, 156.5 (C-1), 148.5 (C-3), 147.4 (C-2), 145.5 (C-6a), 144.6 (C-5), 134.6 (C-11a), 134.4 (C-10), 131.4 (C-7a), 131.1 (C-11c), 129.0 (C-8), 128.2 (C-9), 127.7 (C-11), 122.8 (C-3a), $119.2(\mathrm{C}-4), 115.7(\mathrm{C}-11 \mathrm{~b}), 61.8\left(3-\mathrm{OCH}_{3}\right), 61.5$ $\left(2-\mathrm{OCH}_{3}\right), 61.0\left(1-\mathrm{OCH}_{3}\right)$.

\section{BIOASSAY}

The crude extract and pure compounds were assayed for antibacterial activity against the bacteria Bacillus subtilis (ATCC 11774), Staphylococcus aureus (ATCC 11632), Enterobacter aerogenes (ATCC 13048) and Escherichia coli (ATCC 10536). The crude extract was dissolved at a concentration of $2 \mathrm{mg} / \mathrm{mL}$ and pure compounds were prepared at $1 \mathrm{mg} / \mathrm{mL}$ in DMSO. The amounts of crude extract and pure compounds on the discs were 20 and 10 $\mu \mathrm{g}$, respectively, whereas the standard Chaloramphenicol was $30 \mu \mathrm{g}$.

\section{RESULTS AND DISCUSSION}

Compound 1 (3.4 mg) was isolated as white needles. The ESI-MS gave molecular ion at $\mathrm{m} / \mathrm{z} 323.0891[\mathrm{M}+\mathrm{Na}]^{+}$, which corresponded to the molecular formula $\mathrm{C}_{17} \mathrm{H}_{16} \mathrm{O}_{5}$. The UV spectrum in methanol showed absorption at 226 , 292 and $357 \mathrm{~nm}$. The prominent and broad absorption at $3241 \mathrm{~cm}^{-1}$ in the FTIR spectrum indicated the presence of hydroxyl $(\mathrm{OH})$ group together with prominent band at $1623 \mathrm{~cm}^{-1}$ for the existence of carbonyl $(\mathrm{C}=\mathrm{O})$ group. The ${ }^{1} \mathrm{H}$ NMR spectrum showed two two-proton doublets at $\delta_{\mathrm{H}}$ $6.83(\mathrm{H}-3, \mathrm{H}-5)$ and $7.18(\mathrm{H}-2, \mathrm{H}-6)$ corresponding to four aromatic protons of ring $B$. Two doublet signals at $\delta_{H}$ 5.95 and 6.02 were assigned to $\mathrm{H}-3^{\prime}$ and $\mathrm{H}-5^{\prime}$ of ring A. Two distinct methoxy signals at $\delta_{\mathrm{H}} 3.75$ and 3.88 , which were positioned at C-4 (ring B) and C-6' (ring A). A very downfield, signal at $\delta_{\mathrm{H}} 13.91$ was attributed to $2^{\prime}-\mathrm{OH}$ and another one singlet signal at $\delta_{\mathrm{H}} 9.55$ was assigned to $4^{\prime}-\mathrm{OH}$. Two one-proton doublet signals at $\delta_{\mathrm{H}} 7.74$ and $7.90(J=15.3 \mathrm{~Hz})$ were attributed to trans $\mathrm{H}-\beta$ and $\mathrm{H}-\alpha$, respectively. Through comparison of the observed data with the literature, compound 1 is identified as $2^{\prime}, 4^{\prime}$-dihydroxy$4,6^{\prime}$-dimethoxychalcone $[10,12]$. This compound was also isolated from other genus of Annonaceae family i.e. Goniothalamus gardneri (Seidel et al. 2000).

Compound 2 (3.2 mg) appeared as yellow needles. The ESI-MS gave a molecular ion of $337.1005[\mathrm{M}+\mathrm{Na}]^{+}$consistent with molecular formula of $\mathrm{C}_{18} \mathrm{H}_{18} \mathrm{O}_{5}$. Additionally, the FTIR spectrum showed the presence of $\mathrm{OH}$ at $3306 \mathrm{~cm}^{-1}$ and $\mathrm{C}=\mathrm{O}$ at $1639 \mathrm{~cm}^{-1}$. The ${ }^{1} \mathrm{H}$ NMR spectrum showed distinct methoxy signals at $\delta_{\mathrm{H}} 3.88(\mathrm{C}-3), 3.90(\mathrm{C}-4 / \mathrm{C}-6)$ and 3.94 (C-4/C-6) of ring B. Furthermore, two one-proton singlet signals at $\delta_{H} 6.09$ and 6.61 were attributed to $\mathrm{H}-5$ and $2-\mathrm{OH}$ of ring B. The five aromatic signals at $\delta_{\mathrm{H}} 7.48(2 \mathrm{H}, t, J$ $\left.=7.3 \mathrm{~Hz}, \mathrm{H}-3^{\prime}, \mathrm{H}-5^{\prime}\right), 7.55\left(1 \mathrm{H}, t, J=7.3 \mathrm{~Hz}, \mathrm{H}-4^{\prime}\right)$ and $8.04\left(2 \mathrm{H}, d, J=7.3 \mathrm{~Hz}, \mathrm{H}-2^{\prime}, \mathrm{H}-6^{\prime}\right)$ were corresponding to the protons of ring A. The two one-proton doublet signals $(J=16.2 \mathrm{~Hz})$ at $\delta_{\mathrm{H}} 8.00$ and 8.23 were assigned to trans $\mathrm{H}-\alpha$ and $\mathrm{H}-\beta$, respectively. Through comparison of the observed data with the literature, compound 2 is identified as tepanone (Colegate et al. 1992).

Compound 3 was isolated as orange needles. Its ESIMS gave a molecular ion of $\mathrm{m} / \mathrm{z} 322.1098[\mathrm{M}+\mathrm{H}]^{+}$, which corresponds to the molecular formula $\mathrm{C}_{19} \mathrm{H}_{15} \mathrm{O}_{4} \mathrm{~N}$. The FTIR spectrum showed the presence of lactam carbonyl group at $1657 \mathrm{~cm}^{-1}$. The ${ }^{1} \mathrm{H}$ NMR spectrum confirmed the presence of three methoxy groups at $\delta_{H} 4.09,4.11$ and 4.20. The aromatic protons of ring $\mathrm{B}$ showed two one-proton doublets signals at $\delta_{\mathrm{H}} 8.22$ and $8.79(\mathrm{~J}=5.4 \mathrm{~Hz})$ due to $\mathrm{H}-4$ and $\mathrm{H}-5$. The four aromatic protons at $\delta_{\mathrm{H}} 7.54(t, J=$ $7.7 \mathrm{~Hz}, \mathrm{H}-9), 7.75$ ( $d t, J=1.2,7.7 \mathrm{~Hz}, \mathrm{H}-10), 8.58$ (dd, $J$ $=1.2,7.7 \mathrm{~Hz}, \mathrm{H}-8)$ and $9.11(d, J=8.7 \mathrm{~Hz}, \mathrm{H}-11)$, which were ascribed to the protons of the unsubstituted D ring of the aporphine nucleus [14]. The signal of H-11 was more downfield due to the presence of the three methoxy groups at ring A, which deshielded the proton. From the $\mathrm{X}$-ray crystallography data, compound 3 was comfirmed as $o$-methylmoschatoline. Figure 1 shows the structure of compound 3 by X-ray crystallography. This compound was isolated from genus Xylopia (Annonaceae) i.e. $X$. championii (Wijeratne et al. 1996) and X. ferruginea (Zawawi et al. 2012). 
<smiles>COc1ccc(/C=C/C(=O)c2c(O)cc(O)cc2OC)cc1</smiles><smiles>COc1c(OC)c2c3c(nccc3c1OC)C(=O)c1ccccc1-2</smiles>

compound 3<smiles>COC1=C(/C=C/C(=O)c2ccccc2)CC=C1</smiles>

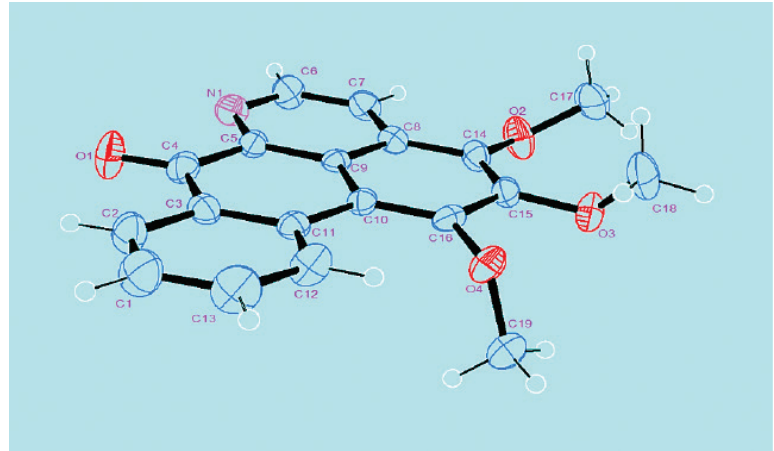

FIGURE 1.o-Methylmoschatoline structure by X-ray crystallography

TABLE 1. Antibacterial activity of the crude extract and compounds 1-3

\begin{tabular}{lcccc}
\hline \multirow{2}{*}{ Sample } & \multicolumn{4}{c}{ Inhibitory zone $(\mathrm{mm})$} \\
& B. subtilis & S. aureus & E.aerogenes & E. coli \\
\hline Crude extract & - & - & - & - \\
1 & $11.5 \pm 0.0$ & - & $12.0 \pm 0.0$ & $6.0 \pm 0.7$ \\
2 & - & - & - & - \\
3 & $35 \pm 0.0$ & $26.5 \pm 0.0$ & - & - \\
Chloramphenicol & $23 \pm 0.0$ & $20.5 \pm 0.2$ & $26 \pm 0.7$ & $26 \pm 0.3$ \\
\hline
\end{tabular}

The extract and compounds isolated from $E$. cuneifolia were evaluated for antibacterial activity. The crude extract did not have antibacterial activity. Compounds 1 showed inhibitory against Bacillus subtilis, Enterobacter aerogenes and Escherichia coli, whereas compound 3 exhibited very strong activities against $B$. subtilis and Staphylococcus aureus. The inhibitory values are shown in Table 1.

\section{CONCLUSION}

Chromatographic separation of chloroform extract of the twigs of Ellipeia cuneifolia yielded three compounds as $2^{\prime}, 4^{\prime}$-dihydroxy-4,6'-dimethoxychalcone, tepanone and
$O$-methylmoschatoline. In addition, tepanone could be considered as a chemical marker for this species.

\section{ACKNOWLEDGEMENTS}

We would like to thank the Ministry of Education, Malaysia for the financial support under UKM-DLP-2012-033 and UKM-DLP-2013-018 grants and postgraduates scholarship under MyBrain15. Special thanks to School of Chemical Sciences and Food Technology, Faculty of Science and Technology, UKM and Centre for Research and Innovation Management (CRIM) UKM for the technical support on NMR, LC-MSToF, UV and FTIR instrumentation. 


\section{REFERENCES}

Colegate, S.M., Din, L.B., Ghisalberti, E.L. \& Latiff, A. 1992. Tepanone, a retrochalcone from Ellipeia cuneifolia. Phytochemistry 31: 2123-2126.

Kessler, P.J.A. 1993. Annonaceae. In The Families and Genera of Vascular Plants. Volume II. Flowering Plants. Dicotyledons: MagnoliidHamamelid and Caryophyllid Families, edited by Kubitzki, K., Rohwer, J.G. \& Bittrich, V. Berlin: SpringerVerlag. pp. 93-129.

Ridley, H.N. 1922. The flora of the Malay Peninsula. Vol II. Reprinted 1967. London: L. Reeve \& Co.

Seidel, V., Bailleul, F. \& Waterman, P.G. 2000. (Rel)$1 \beta, 2 \alpha$-di-(2,4-dihydroxy-6-methoxybenzoyl)-3 $\beta, 4 \alpha$-di-(4methoxyphenyl)-cyclobutane and other flavonoids from the aerial parts of Goniothalamus gardneri and Goniothalamus thwaitesii. Phytochemistry 55: 439-446.

Sinclair, J. 1955. A revision of the Malayan Annonaceae. Gardens' Bulletin Singapore 14(2): 149-516.

Wijeratne, E.M.K., Hatanaka, Y., Kikuchi, T., Tezuka, Y. \& Gunatilaka, A.A.L. 1996. A dioxoapophine and other alkaloids of two Annonaceous plants of Sri Lanka. Phytochemistry 42: 1703-1706.

Zawawi, N.K.N.A., Ahmat, N., Ahmad, R., Jaafar, F.M. \& Ghani, N.A. 2012. Oxoaporphine alkaloids and flavonols from Xylopia ferruginea (Annonaceae). Biochemical Systematics and Ecology 43: 7-9.
Hasliza Yusof, Laily B. Din, Wan A. Yaacob* \& Bohari M. Yamin School of Chemical Sciences and Food Technology

Faculty of Science and Technology

Universiti Kebangsaan Malaysia

43600 Bangi, Selangor D.E.

Malaysia

Nazlina Ibrahim

School of Biosciences and Biotechnology

Faculty of Science and Technology

Universiti Kebangsaan Malaysia

43600 Bangi, Selangor D.E.

Malaysia

A. Latiff

School of Environmental and Natural Resource Sciences Faculty of Science and Technology

Universiti Kebangsaan Malaysia

43600 Bangi, Selangor D.E.

Malaysia

*Corresponding author; email: wanyaa@ukm.edu.my

Received: 6 October 2014

Accepted: 9 April 2015 